\title{
DETERMINATION OF HETEROSIS, GENE ACTION AND THE NATURE OF RESISTANCE TO FUSARIUM WILT DISEASE (FUSARIUM OXYSPORUM F.SP CAPSICI) IN SWEET PEPPER HYBRIDS
}

\author{
Abeer A. El. Soliman ${ }^{(1)}$ and Eman Y. Khafagi ${ }^{(2)}$ \\ (1) Vegetables Breeding Dept., Hort. Res. Inst., Agricultural Research Center (ARC), Giza, \\ Egypt. \\ (2) Plant Pathology Res. Inst., Agricultural Research Center (ARC), Giza, Egypt. \\ Received: Oct. 19, 2017 \\ Accepted: Nov. 1, 2017
}

ABSTRACT: Four parental genotypes from a Center of Germplasm Netherland (CGN) i.e. 1 (PI 23235), 2 (PI 17171), 3 (PI 23096) and 4 (PI 17150) and their six $F_{1}$ hybrids in a diallel cross system without reciprocals were used to estimate combining ability (general and specific) and heterosis percentage relative to both mid and better parents and potence ratios for some characters in pepper (Capsicum annuum L.). The experiment was conducted at Kaha Research Farm, Kaliobia Governorate under unheated plastic house during two successive seasons 2015-2016. Survey was conducted at Kaliobia Governorate during 2015 and 2016 and the pathological studies were carried out at the Plant Pathology Research Institute, Agricultural Research center, Giza Governorate. The studies showed that Fusarium oxysporum f.sp capsici (isolate 3) was the highest in frequency and the level of pathogenicity. The susceptibility of 10 genotypes to Fusarium oxysporum f.sp. capsici (isolate 3) indicated that two $F_{1}$ crosses $2 \times 4$ and $3 \times 4$ were resistant to Fusarium oxysporum f.sp. capsici (isolate 3). The correlation analysis revealed that the disease severity on roots was significantly correlated with four traits; weight/plant (kg), number of fruits /plant, number of days to $50 \%$ flower anthesis and fruit length (cm). In contrast, vascular discoloration was significantly correlated with three traits; weight/plant ( $\mathrm{kg})$, number of fruits /plant, and fruit length (cm).

The 10 genotypes (4 parents and 6 hybrids) were evaluated for yield ;yield components and fusarium wilt resistance to determine the combining ability and heterosis effects. The obtained results reflected that the mean squares for both general combining ability (GCA) and specific combining ability (SCA) were significant for all studied traits except SCA in fruit shape index and fruit flesh thickness, suggesting the presence of both additive and non-additive gene effects in the inheritance of the various studied characters. Estimates of SCA effects showed that the $F_{1}$ crosses $2 \times 4$ and $2 \times 3$ reflect the highest value in most studied traits; i.e. total yield as weight and number, fruit length and low disease severity of roots and shoots. Hybrid vigour was documented for total yield, as well as, most fruit characters and disease severity. In some crosses, high rate of parent heterosis and potence ratio values were attained for these traits supporting the over dominance hypothesis.

Key Words: Pepper - Combining ability- Heterosis - Potence ratio - fusarium wilt Resistance

\section{INTRODUCTION}

Pepper (Capsicum annuum L.) is the third most important crops of the Solanaceae, which is widespread due to its high nutrition value and the taste of the fruits. Pepper is cultivated globally for their medicinal, nutritional and ornamental uses
(Bosland and Votava, 2012). Sweet pepper is usually susceptible to several fungal diseases causing severe deterioration in the yield quantity and quality components (Black et al. 1991). Losses due to Fusarium wilt were severe, up to $35 \%$ of plants were 
affected in a single field (Roberts et al. 2004).

Other Fusarium spp. associated with pepper roots cause decline symptoms and root rots but not a vascular wilt. The phytopathogenic fungus Fusarium oxysporum Schlecht is considered the most important causal wilting agent associated with sweet pepper wilt disease (Attia and Abada 1994 and Abada 1994). The proposed name for the causal organism of Fusarium wilt in pepper is Fusarium oxysporum (Schlect.) emend. Snyd. \& Hans. F. sp. capsici f. sp. nov. (Rivelli 1989). Earlier reports identified it as Fusarium oxysporum var. vasinfectum (Sherf and $\mathrm{McNab}$ 1986). The symptoms of Fusarium wilting disease including discoloration of tissues and plugging of vessels by hyphae, vein clearing on cotyledonary and first leaves and reduction in size of leaves and bolls (Singh, 1989). The fungus can survive for more than 30 years as chlamydospores in infested plant debris or in the roots of alternative hosts (Agrios, 1997).

The wilt disease, incited by a number of pathogens, is the devastating soil-borne disease and hence difficult to manage (Rather et al. 2012). The disease has been observed to be caused by Fusarium oxysporum f.sp capsici, exorbitant losses and lack of information regarding integrated management of wilt complex disease using different methods such as bio-control agents and chemicals and grafting and agriculture practice, the present studies were conducted to evolve the effective management strategies involving breeding of resistant cultivars which is effective and safe method to protect the pepper plants (Sarhan and Sharif 1986 and Attia et al. 2003).

So, increasing yield and improving fruit characters could be achieved through breeding programs. The majority of modern commercial varieties of sweet pepper are $F_{1}$ hybrids because of the obvious economic advantage of the hybrids in comparison with the traditional varieties. Information on combining ability facilitates the choice of suitable parents for hybridization program to develop $F_{1}$ hybrids. Hence the diallel cross mating gives a fairly good idea of both general and specific combining abilities of parents and hybrid combinations respectively. Pepper is one of the most suitable crops for exploitation of heterosis in the form of $F_{1}$ hybrid as the hybrids are the most efficient forms to get increase in productivity in per unit area which can be achieved by utilizing hybrid vigor (Pandy et al. 2012).

The presence of heterosis for yield and yield attributing traits in capsicum has also been reported earlier by several workers. (Sood and Kaul, 2006; El-Sayed, 2008 and Jagdeesha and Wali, 2005). The development of $F_{1}$ hybrids and identification of superior genotypes becomes imperative for promoting its production, productivity and quality produce.

The role of General and specific combining ability (GCA and SCA) for yield and yield component in pepper has also been reported by several workers viz., Kamble et al. (2009), who reported that variances due to GCA and SCA showed that the non-additive gene action was predominant, though the additive component was also significant. The same conclusion was reported by Fekadu et al. (2009) for the studied characters i.e. plant and fruit traits with few exceptions. They mentioned also that the additive gene effect was more important than non-additive ones in the inheritance of pericarp thickness, locule number and fruit length of sweet pepper.

Khalil and Hatem (2014) reported the mean squares for GCA and SCA were significant highly for all the studied traits suggesting the presence of both additive and non-additive gene effects in the inheritance of the various studied characters. However, the high ratio of GCA: SCA mean squares showed that GCA effect was more important than SCA effect. The 
preponderance of GCA effects implied that these characters would respond favorably to direct selection.

This investigation was designed to study the genetics of the studied characters and on the extent of heterosis and combining ability for yield, its yield attributing traits and fusarium wilt resistance in sweet pepper.

\section{MATERIALS AND METHODS}

This study was carried out in 2015 and 2016 at Kaha Research Farm, Kaliobia Governorate under unheated plastic house (9 m x $59 \mathrm{~m}, 4 \mathrm{~m}$ height). Four pepper genotypes from Center of Germplasm Netherland (CGN) Viz. 1 (PI 23235), 2 (PI 17171), 3 (PI 23096) and 4 (PI 17150) were selfed for one generation to keep its homozygosity and homogeneity. Parents were crossed to produce the $F_{1}$ hybrid seed in Diallel cross design, without reciprocals. Seed of the four parental lines and their six $\mathrm{F}_{1}$ 's crosses were planted in seedling trays on the last of June in the two seasons (2015 and 2016). The seedlings were 45 days old they were transplanted to the unheated plastic house. The experimental design was randomized complete block design with three replicates. Each plot contained 4 parents and their $6 \quad F_{1}$ hybrids. Each replicate consisted of 10 plants for each population spaced $50 \mathrm{~cm}$ apart. Five pepper fruits at green maturity were randomly taken two times to determine the fruit characters. The studied characters were total yield as fruit number and weight $(\mathrm{kg})$ per plant, average fruit weight $(\mathrm{g})$, fruit length and fruit diameter $(\mathrm{cm})$, fruit flesh thickness $(\mathrm{cm})$ and total soluble solids (TSS) which was determined by a hand refractometer.

\section{Pathological studies: \\ a) Disease survey}

Survey of wilting diseases was carried out on sweet pepper plantations collected from Kaliobia governorate. Samples bearing Fusarium wilting disease were randomly collected from different locations and then transferred to the laboratory for the fungal pathogen isolation.

\section{b) Isolation and identification of the causal fungus}

The root and stem samples were washed under running tap water, Parts of stems and roots showing rotting discoloration or wilting symptoms were picked up and cut into small pieces $(0.5 \mathrm{~cm})$ then surface sterilized by soaking in $0.1 \%$ sodium hypochlorite for 2 minutes followed by washing (three times) with sterilized distilled water. The surface disinfected pieces were then properly dried under sterilized conditions (sterile laminar flow hood) and then transferred individually to PDA plates and incubated at $25 \mathrm{C}^{\circ} \pm 2 \mathrm{C}^{\circ}$ for 5 days. After the incubation period, the developed fungal colonies were firstly purified either by using hyphal tip or single spore technique. The growing fungi were identified based on their macroscopic and morphological characters according to Booth and Waterston (1964), Domsch et al. 1980 and Nelson et al. (1983).

The obtained culture isolates were maintained on PDA tubes and preserved in refrigerator at $5 \mathrm{C}^{\circ}$ for further study. The frequency of the isolated fungi was calculated separately for each of the collected samples.

\section{c) Pathogenicity Test}

Class bottles (500 $\mathrm{ml}$ in volume) contain corn meal-sand medium $(3: 1 \mathrm{w} / \mathrm{w})$ were autoclaved at $121 \mathrm{C}^{\circ}$ for $30 \mathrm{~min}$ the sterilized bottles were then inoculated with discs $(5 \mathrm{~mm})$ of five day - old culture of the nine isolates individually namely Fusarium oxysporum including (isolate 1,2 and 3), Verticillium albo-atrum, Rhizoctonia solani, Fusarium solani, Fusarium semitictum, Fusarium moniliforme and Sclerotium rolfsii and incubated at $25 C^{\circ}$ for 15 days .

Soil infestation was carried out by mixing fungal inoculum of each isolate with sterilized potted - pots at the rate of $3 \%$ $(w / w)$. The infested soil was watered for 7 
days to enhance growth and distribution of the fungal inoculum.

Soil provided with the equal amounts of the un-inoculated substrate were added and free fungal inoculum was used as control. Two pepper seedlings of California Wonder as a susceptible cultivar of 4 weeks old age were transplanted into the soil of each pot. Four replicate pots were used for each tested isolate. The disease severity of the pepper wilt disease was determined after 60 days from seedlings transplanting. The experiment was done in pots experiments.

\section{d) Evaluation of pepper genotypes for Fusarium wilt resistance}

The selected isolate Fusarium oxysporum f.sp capsici (isolate 3) was exploited for evaluating the resistant or susceptibility of pepper plants to Fusarium wilt according to its highest frequency and pathogenicity test .The experiment was done in pots experiments.

\section{Inoculum preparation}

Class bottles ( $500 \mathrm{ml}$ in volume) contain corn meal-sand medium $(3: 1 \mathrm{w} / \mathrm{w})$ were autoclaved at $121 \mathrm{C}^{\circ}$ for $30 \mathrm{~min}$ the sterilized bottles were then inoculated with discs $(5 \mathrm{~mm})$ of five day - old culture of Fusarium oxysporum f.sp capsici (isolate 3) and incubated at $25 \mathrm{C}^{0}$ for 15 days. Soil infestation was carried out by mixing fungal inoculum with sterilized potted - pots at the rate of $3 \%(w / w)$. The infested soil was watered for 7 days to enhance growth and distribution of the fungal inoculum. Two pepper seedlings [i.e. 1 (PI 23235), 2 (PI 17171), 3 (PI 23096) and 4 (PI 17150) and their six $F_{1}$ hybrids $(1 \times 2,1 \times 3,1 \times 4,2 \times 3,2 \times 4$ and $3 \times 4$ ) and three controls (cv. California Wonder 300 TMR, cv. Sweet banana and hybrid Gideon) of sweet pepper of 4 weeks old age were transplanted into the soil of each pot. Four replicate pots were used for each tested genotypes. The disease severity of the pepper wilt disease was determined after 60 days from seedlings transplanting.

\section{Disease assessment}

The disease severity (D.S.) was calculated according to The Horsfall and Barratt scale (1945) Table 1. The scale is widely used as visual assessment scale for evaluating plant disease.

The formula for calculating the disease severity is as following:

$\mathrm{DSI}=\sum(($ Disease severity scale $\mathrm{x}$ number of plants in each scale) / (The highest numerical scale index $x$ total number of plants)) $\times 100$.

Table 1. The Horsfall and Barratt disease scale

\begin{tabular}{|c|c|}
\hline Rating & Infection \% \\
\hline 1 & 0 \\
\hline 2 & $0-3$ \\
\hline 3 & $3-6$ \\
\hline 4 & $6-12$ \\
\hline 5 & $12-25$ \\
\hline 6 & $25-50$ \\
\hline 7 & $50-75$ \\
\hline 8 & $75-87$ \\
\hline 9 & $87-94$ \\
\hline 10 & $94-97$ \\
\hline 11 & $97-100$ \\
\hline
\end{tabular}




\section{Statistical analysis}

Means and variances were calculated for each treatment where the means were statistically compared for significant differences using L.S.D (Snedecor and Cochran, 1990). Combined analysis of variance for the two years was computed for all traits according to Koch and Sen (1968).

Correlation analysis was used to evaluate the relationship between disease severity and yield components. Correlation analysis was carried out by a computerized program (SPSS Inc., version 13.0, Chicago, IL, USA ).

The analysis of general and specific combining abilities (GCA and SCA) was calculated according to Griffing (1956) method 2 model 1.

Average degree of heterosis (ADH\%) was estimated as the increase or decrease percent of $F_{1}$ performance over the midparent (MP) and better parent (BP), (Sinha and Khanna, 1975) as following:

Based on MP $=\left(\overline{\mathrm{F}}_{1}-\overline{\mathrm{MP}} / \overline{\mathrm{MP}}\right) \times 100$

Based on $\left.\mathrm{HP}=\overline{\left(\overline{F_{1}}\right.}-\overline{\mathrm{HP}} / \overline{\mathrm{HP}}\right) \times 100$

Potence ratio $(\mathrm{PR})$ was estimated to determine the nature of dominance and its direction (Smith, 1952) as following:
Potence ratio $(P R \%)=\overline{F_{1}}-\overline{M P} / 1 / 2(\overline{P 2}-\overline{P 1})$. Where: $\overline{\mathrm{MP}}, \overline{\mathrm{BP}}, \overline{\mathrm{F}_{1}}, \overline{\mathrm{P} 1}$ and $\overline{\mathrm{P} 2}$ are the midparents, mean of best parent in the trait,

$\bar{F}_{1}$ hybrids and the means of the second (the better parent) and first parents, respectively.

\section{RESULTS AND DISCUSSION}

\section{a) Fungi associated with stem and roots of diseased sweet pepper}

Nine fungi i.e., Fusarium oxysporum including (isolate 1,2 and 3), Verticillium albo-atrum, Rhizoctonia solani, Fusarium solani, Fusarium semitictum, Fusarium moniliforme and Sclerotium rolfsii were isolated from the collected stem and root samples of wilted sweet pepper. Analysis of variance indicated highly significant difference among the frequency of fungi in two seasons (Table 2). The frequency data of fungal species recovered from Kaliobia, indicated that Fusarium oxysporum (isolate 3), (33.00 \% and $36.25 \%$ in 2015 and 2016 , respectively were recovered more frequently, followed by Verticillium alboatrum $20.75 \%$ and $22.50 \%$ in 2015 and 2016, respectively. While Fusarium solani and Fusarium moniliforme (5.50\% in 2016 ) were recovered in less frequently (Table 2 ).

Table 2. Frequency (\%) of fungi isolated from pepper in two seasons (2015 and 2016 ) .

\begin{tabular}{|c|c|c|}
\hline Fungus & $\begin{array}{c}\text { Season } \\
2015\end{array}$ & $\begin{array}{c}\text { Season } \\
2016\end{array}$ \\
\hline Fusarium oxysporum (isolate 1) & 24.00 & 26.75 \\
\hline Fusarium oxysporum (isolate 2) & 29.00 & 30.25 \\
\hline Fusarium oxysporum (isolate 3 ) & 33.00 & 36.25 \\
\hline Verticillium albo-atrum & 20.75 & 22.50 \\
\hline Rhizoctonia solani & 5.25 & 6.00 \\
\hline Fusarium solani & 4.75 & 5.50 \\
\hline Fusarium semitictum & 6.75 & 7.25 \\
\hline Fusarium moniliforme & 5.25 & 5.50 \\
\hline Sclerotium rolfsii & 5.50 & 6.50 \\
\hline L.S.D $(P \leq 0.05)$ & 4.17 & 4.92 \\
\hline
\end{tabular}




\section{b) Pathogenicity Test}

Data presented in Table (3) showed that the tested isolates significantly differed in their effect on sweet pepper plants.

Isolates of F.oxysporum f.sp. capsici were more virulent compared with other tested fungi. Among the tested isolates F.oxysporum f.sp. capsici (isolate 3) was the most virulent isolate.

Whereas Verticillium albo-atrum, Rhizoctonia solani, Fusarium solani and Fusarium semitictum were moderately virulent . Other tested fungi Fusarium moniliforme and Sclerotium rolfsii where less virulence .

Similarly, different investigations found variation between isolates of Fusarium oxysporum in their virulence (Abada 1994 , Attia and Abada 1994 and Ferniah et al 2014 ).
According to the highly pathogenic isolates we taken Fusarium oxysporum f.sp capsici (isolate 3 ) to make the evaluation study.

The Fusarium oxysporum Schlecht is associated with wilt disease of sweet pepper and also reported as the causal agent of wilt in sweet pepper (Capsicum annum) (Abada, 1994, Mushtaq and Hashmi 1997, Ferniah et al. 2014 and Joshi et al. 2015). Fusarium wilt group is a vascular fungus caused by a xylem pathogen called $F$. oxysporum. In this group, $F$. oxysporum has several specialized forms known as formae specialis (f.sp.) infecting a variety of hosts causing various plant diseases (Agrios, 1988).

The more detailed tests confirmed that F.oxysporum f.sp. capsici is specific for pepper plant. Recently, F. oxysporum f.sp. capsici was reported as pathogen to sweet pepper (Rivelli, 1989 and Lomas-Cano et al. 2016).

Table 3 . Reaction of nine fungi isolated from different locations of Kaliobia governorate against soil borne disease.

\begin{tabular}{|c|c|}
\hline Isolated fungi & $\begin{array}{c}\text { Disease severity \% of pepper } \\
\text { wilt after } 60 \text { days from transplanting }\end{array}$ \\
\hline Fusarium oxysporum f.sp capsici (isolate 1) & 26.5 \\
\hline Fusarium oxysporum f.sp caspici (isolate 2) & 31.6 \\
\hline Fusarium oxysporum f.sp capsici (isolate 3 ) & 36.4 \\
\hline Verticillium albo-atrum & 23.7 \\
\hline Rhizoctonia solani & 22.5 \\
\hline Fusarium solani & 18.6 \\
\hline Fusarium semitictum & 15.7 \\
\hline Fusarium moniliforme & 11.7 \\
\hline Sclerotium rolfsii & 8.2 \\
\hline Control (without fungus) & 0.0 \\
\hline L.S.D $(P \leq 0.05)$ & 5.4 \\
\hline
\end{tabular}




\section{c- Mean performance:-}

The significant differences among the evaluated genotypes for all studied characters were observed indicating wide diversity among the parental materials used in this study.

\section{1- Total yield as weight}

The mean performance of the evaluated $F_{1}$ hybrids, their parents and three controls for some vegetative and fruit characteristics are presented in Table 4. Significant differences were found for total yield as weight. The parental performance for total yield as weight (Table 4) ranged from 2.23 (P4) to 3.1 (P1) kg/plant. The corresponding set of $F_{1}$ hybrids ranged from $3.18(2 \times 3)$ to $4.15(2 \times 4) \mathrm{kg} / \mathrm{plant}$. Controls ranged from $1.6 \mathrm{~kg} /$ plant (California Wonder $300 \mathrm{TMR}$ ) to $2.3 \mathrm{~kg} /$ plant (Gideon) with grand mean 2.87 .

\section{2- Total yield as number}

The parental performance for total fruit as number (Table 4) ranged from 13.17 (P2) to 26.42 (P3). The corresponding set of $F_{1}$ hybrids ranged from $17.83(1 \times 2)$ to 26.33 $(3 \times 4)$. Controls ranged from 10.63 (California Wonder $300 \mathrm{TMR}$ ) to 27.58 (Sweet banana) with grand mean 19.42 .

\section{3- Number of days to $\mathbf{5 0 \%}$ flower anthesis}

The parental performance for number of days to $50 \%$ flower anthesis. (Table 4) ranged from 41.0 day (P4) to 44.83 day (P3). The corresponding set of $F_{1}$ hybrids ranged from 36.33 day $(1 \times 4)$ to $41.50(3 \times$ 4). Controls ranged from 43.50 day (Sweet banana) to 46.83 day (California Wonder 300 TMR) with grand mean 44.21.

\section{4- Average fruit weight}

The parental performance for fruit weight (Table 4) ranged from $114.3 \mathrm{~g}$ (P3) to 182.6 $g$ (P2) with grand mean 160.03. The corresponding set of $F_{1}$ hybrids ranged from $159.0 \mathrm{~g}(3 \times 4)$ to $195.4(1 \times 2)$. Controls ranged from $66.7 \mathrm{~g}$ (Sweet banana) to 177.3

$\mathrm{g}$ (Gideon) with grand mean 161.03.

\section{5- Fruit flesh thickness}

The parental performance for fruit flesh thickness (Table 4) ranged from $0.26 \mathrm{~cm}$ (P2) to $0.4 \mathrm{~cm}$ (P1). The corresponding set of $F_{1}$ hybrids ranged from $0.30 \mathrm{~cm}(1 \times 3)$ to $0.45 \mathrm{~cm}(2 \times 3)$. Controls ranged from 0.21 $\mathrm{cm}$ (California Wonder $300 \mathrm{TMR}$ ) to $0.33 \mathrm{~cm}$ (Gideon) with grand mean 0.33.

\section{6- Fruit diameter}

The parental performance for fruit diameter (Table 4) ranged from $6.8 \mathrm{~cm}$ (P3) to $8.5 \mathrm{~cm}$ (P2). The corresponding set of $F_{1}$ hybrids ranged from $7.5 \mathrm{~cm}(1 \times 3)$ to $8.9 \mathrm{~cm}$ $(2 \times 4)$. Controls ranged from $3.6 \mathrm{~cm}$ (Sweet banana) to $6.6 \mathrm{~cm}$ (Gideon) with grand mean 7.5 .

\section{7- Fruit length}

The parental performance for fruit length (Table 4) ranged from $8.4 \mathrm{~cm}$ (P3) to $9.9 \mathrm{~cm}$ (P2 and P4). The corresponding set of $F_{1}$ hybrids ranged from $9.9 \mathrm{~cm}(1 \times 3)$ to 10.4 $\mathrm{cm}(1 \times 2)$. Controls ranged from $7.4 \mathrm{~cm}$ (California Wonder 300 TMR) to $11.7 \mathrm{~cm}$ (Sweet banana) with grand mean 9.8.

\section{8- Fruit shape index}

The parental performance for fruit shape index (Table 4) ranged from 1.1 (P2) to 1.2 (P1, P3 and P4). The corresponding set of $F_{1}$ hybrids ranged from $1.1(1 \times 2,2 \times 3$ and $3 \times 4)$ to $1.3(1 \times 3)$. Controls ranged from 1.3 (California Wonder 300 TMR and Gideon) to 3.2 (Sweet banana) with grand mean 1.3.

\section{9- Total soluble solids}

The parental means for total soluble solids (Table 4) ranged from $4.5 \%$ (P1 and P2) to $5.3 \%$ (P4). The corresponding set of $\mathrm{F}_{1}$ hybrids ranged from $4.1 \%(2 \times 3)$ to $5.5 \%$ $(2 \times 4)$. Controls ranged from $4.3 \%$ (Sweet banana) to $4.5 \%$ (California Wonder 300 TMR and Gideon) with grand mean $4.7 \%$. 


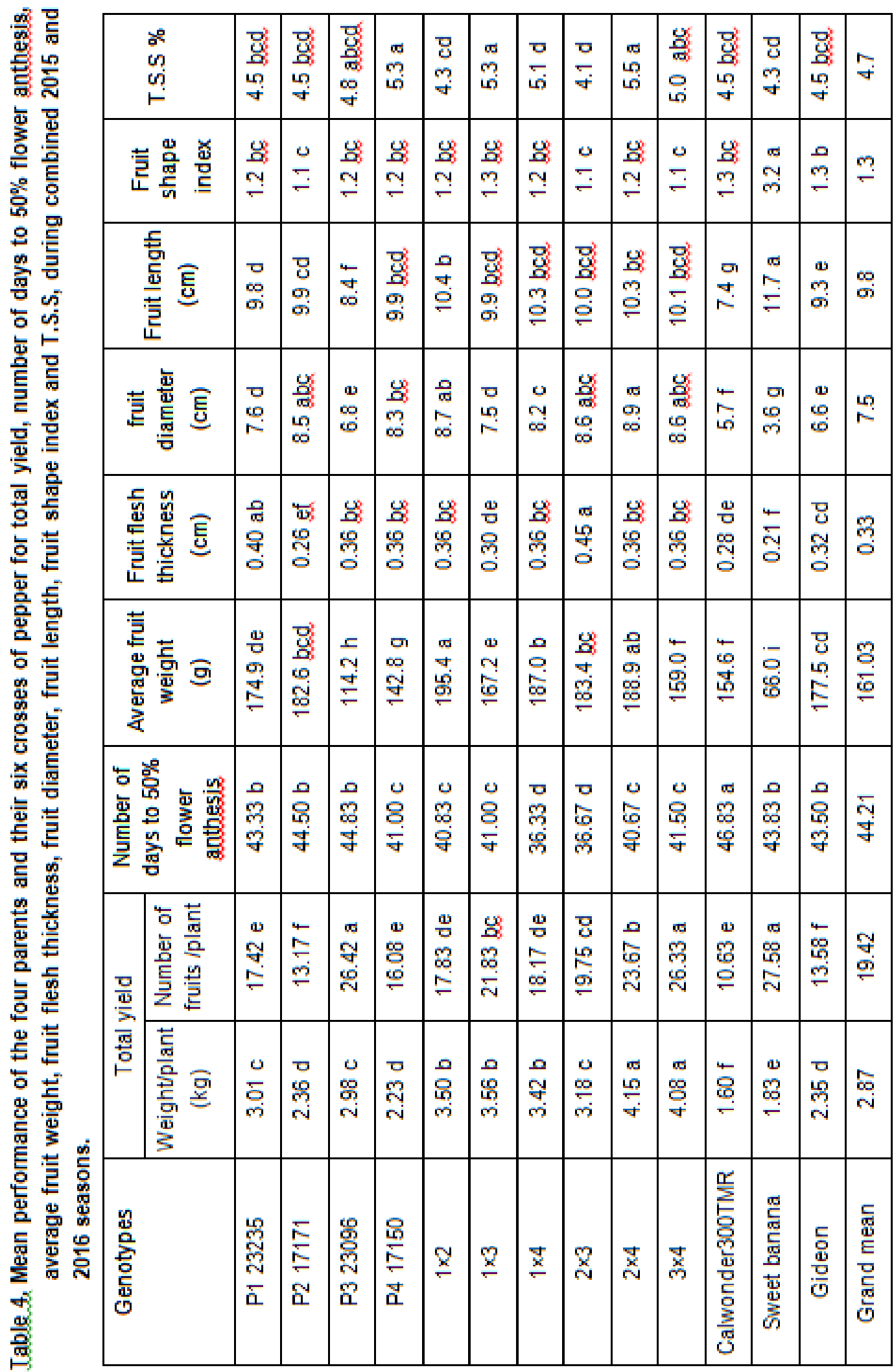




\section{0-Evaluation of pepper genotypes against Fusarium wilt resistance}

The chosen genotypes were evaluated against a selected isolate of Fusarium oxysporum f.sp. capsici (isolate 3 ).

Symptoms of the vascular wilt disease appear initially as a slight yellowing and wilting on the upper leaves. The plant becomes permanently wilted within few days and dies. The dried foliage remains attached to the plant. Brown discoloration of the vascular tissue can be observed by cutting the stem lengthwise (Rivelli,1989). Infected roots are brown (Sherf and McNab,1986). However in several cases other pathogenic Fusarium spp. had been associated with a general plant decline. The symptoms appear as gradual chlorosis of the foliage, thinned canopy, and the plant appears slightly stunted and unthrifty compared to healthy plants.

Based on these symptoms it was concluded that the isolate used in evaluation belong to Fusarium oxysporum f.sp. capsici is involved in pepper wilt .

\section{a) Disease severity on roots}

The disease severity indicated that the hybrids $(2 \times 4),(3 \times 4)$ and $(1 \times 3)$ showed the lowest disease severity. In contrast the genotypes $(2 \times 3)$ and P4 17150 showed the highest disease severity. The other genotypes showed variable levels of disease severity between these two extremes (Table $5)$.

Table 5: Reactions of pepper genotypes against Fusarium oxysporum f.sp capcisi (isolate 3) after 60 days of seedlings transplanting (pots experiment).

\begin{tabular}{|c|c|c|}
\hline Genotypes & $\begin{array}{c}\text { Disease severity on } \\
\text { roots } \\
\%\end{array}$ & $\begin{array}{c}\text { Disease severity on } \\
\text { vascular wilt in stem } \\
\%\end{array}$ \\
\hline P1 23235 & $15.4 \mathrm{f}$ & $12.0 \mathrm{f}$ \\
\hline P2 17171 & $19.2 \mathrm{e}$ & $17.4 \mathrm{e}$ \\
\hline P3 23096 & $21.1 \mathrm{e}$ & $19.2 \mathrm{de}$ \\
\hline P4 17150 & $24.9 \mathrm{~d}$ & $21.7 \mathrm{c}$ \\
\hline $1 \times 2$ & $10.8 \mathrm{~g}$ & $8.9 \mathrm{~g}$ \\
\hline $1 \times 3$ & $6.7 \mathrm{~h}$ & $5.1 \mathrm{~h}$ \\
\hline $1 \times 4$ & $13.5 \mathrm{f}$ & $11.1 \mathrm{fg}$ \\
\hline $2 \times 3$ & $30.3 \mathrm{c}$ & $24.9 \mathrm{c}$ \\
\hline $2 \times 4$ & $3.0 \mathrm{~g}$ & $2.0 \mathrm{i}$ \\
\hline $3 \times 4$ & $4.9 \mathrm{hi}$ & $2.8 \mathrm{hi}$ \\
\hline Calwonder300TMR & $45.9 \mathrm{a}$ & $43.1 \mathrm{a}$ \\
\hline Sweet banana & $5.7 \mathrm{~h}$ & $4.0 \mathrm{hi}$ \\
\hline Gideon & $43.5 \mathrm{a}$ & $40.1 \mathrm{~b}$ \\
\hline Grand mean & 18.83 & 16.33 \\
\hline
\end{tabular}




\section{b) Disease severity on vascular wilt in stem:}

The hybrids $(2 \times 4),(3 \times 4),(1 \times 3)$ and $(1 \times 2)$ showed the lowest disease severity. While, genotypes $(2 \times 3)$ and P4 17150 showed the highest disease severity. The other genotypes showed variable levels of disease severity between these two extremes. Interestingly, it was noticed that the genotypes which showed lowest and highest disease severity on roots are the same genotypes which showed lowest and highest disease severity on vascular wilt in stem (Table 5).

Observing and following the existence of Fusarium wilt disease symptoms in its early stage, is considered one of the core factors in controlling the Fusarium wilt spread. Pathogenic Fusarium species are difficult to control due to their ability to survive in soil for long periods, with or without a host plant, besides their saprophyte condition. Currently effective means of controlling F.oxysporum include: disinfestations of the soil and planting material with fungicidal chemicals, crop rotation with non-hosts of the fungus, or by using resistant cultivars to minimize losses caused by the disease (Wollenweber 1913, Walker 1952 and Agrios, 1988).

\section{c) Correlation analysis}

The statistical analysis revealed that the disease severity on roots was significantly correlated with four traits; weight/plant $(\mathrm{kg})$, number of fruits /plant, number of days to $50 \%$ flower anthesis and fruit length $(\mathrm{cm})$; on disease severity of roots. In contrast, vascular discoloration was significantly correlated with only three traits; weight/plant $(\mathrm{kg})$, number of fruits /plant, and fruit length (cm); Table 6.

Table 6. Correlation between disease severity on roots or vascular discoloration and yield components of pepper.

\begin{tabular}{|l|l|l|}
\hline \multicolumn{1}{|c|}{ Traits } & $\begin{array}{c}\text { Disease severity on } \\
\text { roots }\end{array}$ & $\begin{array}{c}\text { Vascular } \\
\text { discoloration in stem }\end{array}$ \\
\hline 1) Weight/plant (kg) & $-0.683^{*}$ & $-0.643^{*}$ \\
\hline 2) Number of fruits /plant & $-0.754^{* *}$ & $-0.698^{* *}$ \\
\hline 3) Number of days to 50\% flower anthesis & $0.600^{*}$ & $0.408^{(\mathrm{ns})}$ \\
\hline 4) Average fruit weight (g) & $-0.042^{(\mathrm{ns})}$ & $0.039^{\text {(ns) }}$ \\
\hline 5) Fruit flesh thickness(cm) & $-0.184^{(\mathrm{ns})}$ & $0.000^{(\mathrm{ns})}$ \\
\hline 6) fruit diameter (cm) & $-0.324^{(\mathrm{ns})}$ & $-0.239^{(\mathrm{ns})}$ \\
\hline 7) Fruit length (cm) & $-0.757^{* *}$ & $-0.740^{* *}$ \\
\hline 8) Fruit shape index & $-0.177^{(\mathrm{ns})}$ & $-0.227^{(\mathrm{ns})}$ \\
\hline 9) T.S.S \% & $-0.209^{(\mathrm{ns})}$ & $-0.367^{(\mathrm{ns})}$ \\
\hline
\end{tabular}

* Linear Correlation Coefficient $(r)$ is significant at $P \leq 0.05$.

** Linear Correlation Coefficient $(r)$ is significant at $P \leq 0.01$.

n.s non - significant. 
Fusarium oxysporum is a pathogenic fungus common in soils around the world, causing Fusarium wilt of several agricultural and horticultural crops. Fusarium fungus invades root system and xylem vessel. (Stover, 1962). Wilting is most likely caused by a combination of pathogen activities that comprise part of fungus, toxin production, and host defense responses, including production of gels, gums and tyloses, and vessel crushing by proliferation of adjacent parenchyma cells. These significant negative correlations clearly indicated that productivity pepper is greatly affected with Fusarium wilt. Therefore, it is desirable to use highly resistant cultivars to minimize loss of the disease (Agrios, 1988 and Lomas-Cano et al. 2016). Presumably a combination of the processes discussed earlier, namely vessel clogging by mycelium, spores, gels, gums and tyloses and crushing of the vessels by proliferating adjacent parenchyma cell, are responsible for the break of the water economy of the infected plant. When the leaves transpire more water is drawn from root the stomata close and the leaves wilt and finally dies well as death of the rest of the plant (Agrios, 1997, and Jones, 1992).

\section{C- Combining ability.}

The mean squares associated with GCA were significant for all the studied traits. The SCA variance was also significant for all studied characters except fruit flesh thickness and TSS (Table 7). It is evident that non- additive type of gene action was the more important part of the total genetic variability for fruit flesh thickness and TSS $\%$. For the other studied traits, both additive and non-additive types of gene action were involved in determining the performance of crosses progeny. The similar results were obtained by Khalil and Hatem (2014).

Estimates of GCA effects (gi) for individual parental lines in each trait are presented in Table 7. Parental line P4 showed significant negative (gi) effects for number of $50 \%$ days to flowering anthesis, indicating that line could be considered as good combiner for developing early pepper genotype. Parental lines P1 and P4 showed significant negative (gi) effects for disease severity of shoots and disease severity of roots indicating that these lines could be considered as good combiner for developing resistant pepper genotype.

Estimated general combining ability values for the parental lines showed that the best lines (as general combiner) for each character were P3 for total fruits number and weight, $\mathrm{P} 1$ and $\mathrm{P} 2$ for average fruit weight, $P 2$ for fruit length and fruit shape index, P1 for fruit flesh thickness and P 4 for TSS as shown in Table (8).

This result agreed with that reported by Sarujpisit et al. (2012) who found that no parental varieties showed a good performance in all characters but some parents showed high GCA for some characters.

Estimates of SCA effects (si) for individual parental lines in each trait are presented in Table 9. Highly significant estimated SCA values were shown by the combinations $2 \times 4$ and $3 \times 4$ for total fruits number, total fruits weight and disease severity of roots and shoots; $1 \times 4$ and $2 \times 3$ for number of days to $50 \%$ flower anthesis and average fruit weight; $3 \times 4$ for fruit diameter; $2 \times 4$ and $3 \times 4$ for fruit length; $1 \times$ 3 for TSS and disease severity of shoots and roots.

However, the crosses $2 \times 4$ and $3 \times 4$ were the best four studied traits (total yield as weight and number and disease severity for shoots and roots) since they showed the highest SCA values. These findings were similar to those obtained by Kansouh (1989), Huang et al., (2009) and Rêgo et al. (2010). 
Table 7. Mean squares for general combining ability (GCA) and specific combining ability (SCA) for nine studied characters of pepper during season 2016.

\begin{tabular}{|c|c|c|c|c|c|}
\hline Traits & S.V & S.S & M.S & E.F & GCA/SCA \\
\hline Total yield as weight & GCA & 0.40 & 0.15 & $3.20^{*}$ & 0.07 \\
& SCA & 10.25 & 1.70 & $39.00^{*}$ & \\
\hline Total yield as number of & GCA & 330.51 & 110.17 & $27.46^{*}$ & 3.87 \\
& fruit & 170.49 & 28.41 & $7.08^{*}$ & \\
\hline Number of days to 50\% & GCA & 23.16 & 7.72 & $3.91^{*}$ & 0.20 \\
flower anthesis & SCA & 225.80 & 17.63 & $19.06^{*}$ & \\
\hline Fruit weight & GCA & 11896.85 & 3965.61 & $76.13^{*}$ & 4.25 \\
& SCA & 5594.76 & 932.461 & $17.90^{*}$ & \\
\hline Fruit flesh thickness & GCA & 0.09 & 0.03 & $6.07^{*}$ & 7.98 \\
& SCA & 0.02 & 0.003 & 0.76 & \\
\hline fruit diameter & GCA & 7.45 & 2.48 & $16.54^{*}$ & 3.70 \\
& SCA & 4.02 & 0.67 & $4.46^{*}$ & \\
\hline Fruit length & GCA & 4.91 & 1.63 & $14.32^{*}$ & 2.72 \\
& SCA & 3.60 & 0.60 & $5.25^{*}$ & \\
\hline Fruit shape index & GCA & 0.09 & 0.03 & $6.00^{*}$ & 7.89 \\
& SCA & 0.023 & 0.003 & 0.76 & \\
\hline T.S.S & GCA & 3.61 & 1.20 & $4.45^{*}$ & 0.90 \\
& SCA & 8.02 & 1.32 & $4.94^{*}$ & \\
\hline disease severity of roots & GCA & 159.50 & 53.16 & $18.0^{*}$ & 0.12 \\
& SCA & 2646.61 & 441.10 & $149.6^{*}$ & \\
\hline disease severity of & GCA & 240.38 & 80.12 & $46.84^{*}$ & 0.22 \\
shoots & SCA & 2120.19 & 353.36 & $206.58^{*}$ & \\
\hline
\end{tabular}

Degrees of freedom are 3, 6 and 18 for GCA, SCA and error for horticulture character. FT for GCA 3.16 at 0.05 and 2.66 for SCA at 0.05 . Degrees of freedom are 3, 6 and 27 for GCA, SCA and error for Fusarium disease. FT for GCA 2.96 at 0.05 and 2.46 for SCA at 0.05 .

Table 8. General combining ability effects $\left(g_{i}\right)$ of parental lines for studied characters of pepper during season 2016.

\begin{tabular}{|c|c|c|c|c|c|}
\hline \multirow[t]{2}{*}{ Genotypes } & \multicolumn{2}{|c|}{ Total yield } & \multirow{2}{*}{$\begin{array}{c}\text { Number of } \\
\text { days to } 50 \% \\
\text { flower } \\
\text { anthesis }\end{array}$} & \multirow{2}{*}{ Fruit weight } & \multirow{2}{*}{$\begin{array}{l}\text { Fruit flesh } \\
\text { thickness }\end{array}$} \\
\hline & Weight/plant & $\begin{array}{l}\text { Number of } \\
\text { fruits / plant }\end{array}$ & & & \\
\hline P1 23235 & 0.05 & -1.18 & 0.36 & $9.11^{*}$ & $0.05^{*}$ \\
\hline P2 17171 & $-0.11^{*}$ & $-2.31^{*}$ & 0.19 & $14.46^{*}$ & $-0.04^{*}$ \\
\hline P3 23096 & $0.08^{*}$ & $3.40^{*}$ & 0.42 & $-18.51^{*}$ & 0.01 \\
\hline P4 17150 & -0.02 & 0.09 & $-0.97^{*}$ & -5.06 & -0.01 \\
\hline S.E $\left(g_{i}\right)$ & 0.03 & 0.70 & 0.43 & 2.5 & 0.01 \\
\hline S.E $\left(g_{i}-g_{j}\right)$ & 0.17 & 0.15 & 0.81 & 4.1 & 0.03 \\
\hline
\end{tabular}

Significant at 0.05 level of probability according to the $(\mathrm{T})$ test. 
Determination of heterosis, gene action and the nature of resistance

Table 8. Continued

\begin{tabular}{|c|c|c|c|c|c|c|}
\hline Genotypes & $\begin{array}{c}\text { fruit } \\
\text { diameter }\end{array}$ & Fruit length & $\begin{array}{c}\text { Fruit shape } \\
\text { index }\end{array}$ & TSS & $\begin{array}{c}\text { disease } \\
\text { severity } \\
\text { of roots }\end{array}$ & $\begin{array}{c}\text { disease } \\
\text { severity } \\
\text { of shoots }\end{array}$ \\
\hline P1 23235 & -0.19 & 0.04 & $0.05^{*}$ & -0.08 & $-1.82^{*}$ & $-2.30^{*}$ \\
\hline P2 17171 & 0.37 & $0.21^{*}$ & $-0.05^{*}$ & -0.25 & $1.25^{*}$ & $1.52^{*}$ \\
\hline P3 23096 & -0.42 & $-0.43^{*}$ & 0.01 & -0.03 & 1.16 & $1.39^{*}$ \\
\hline P4 17150 & 0.24 & 0.18 & -0.01 & $0.36^{*}$ & -0.55 & -0.61 \\
\hline S.E( $\left(g_{\mathrm{i}}\right)$ & 0.33 & 0.10 & 0.02 & 0.18 & 0.60 & 0.46 \\
S.E(gi $\mathrm{g}_{\mathrm{i}}$-g) & 0.22 & 0.19 & 0.04 & 0.3 & 0.98 & 0.75 \\
\hline
\end{tabular}

Significant at 0.05 level of probability according to the $(\mathrm{T})$ test.

Table 9. Specific combining ability effects $\left(S_{i}\right)$ of six crosses for studied characters of pepper during season 2016.

\begin{tabular}{|c|c|c|c|c|c|}
\hline \multirow[t]{2}{*}{${ }^{\mathrm{Z}}$ Crosses } & \multicolumn{2}{|c|}{ Total yield } & \multirow{2}{*}{$\begin{array}{c}\text { Number of } \\
\text { days to } 50 \% \\
\text { flower } \\
\text { anthesis }\end{array}$} & \multirow{2}{*}{$\begin{array}{l}\text { Average fruit } \\
\text { weight }\end{array}$} & \multirow{2}{*}{$\begin{array}{l}\text { Fruit flesh } \\
\text { thickness }\end{array}$} \\
\hline & Weight/plant & $\begin{array}{l}\text { Number of } \\
\text { fruits / plant }\end{array}$ & & & \\
\hline $1 \times 2$ & $0.32^{*}$ & 1.38 & -0.92 & 3.48 & -0.03 \\
\hline $1 \times 3$ & 0.19 & -1.33 & -0.47 & 9.43 & 0.03 \\
\hline $1 \times 4$ & 0.16 & -0.20 & $-4.42^{*}$ & $13.35^{*}$ & 0.01 \\
\hline $2 \times 3$ & -0.04 & -1.86 & $-5.31^{*}$ & $17.55^{*}$ & -0.02 \\
\hline $2 \times 4$ & $1.02^{*}$ & $4.43^{*}$ & 0.41 & 9.36 & -0.01 \\
\hline $3 \times 4$ & $0.73^{*}$ & $3.38^{*}$ & 0.85 & 11.35 & -0.05 \\
\hline S.E. $\left(s_{\mathrm{ij}}\right)$ & 0.15 & 1.60 & 1.2 & 6.1 & 0.04 \\
\hline S.E. $\left(s_{i i}-s_{j j}\right)$ & 0.17 & 1.63 & 1.1 & 5.8 & 0.04 \\
\hline
\end{tabular}

${ }^{2}$ P1 23235, P2 17171, P3 23096 and P4 17150.

"Significant at 0.05 level of probability according to the $(\mathrm{T})$ test.

Table 9. Continued

\begin{tabular}{|c|c|c|c|c|c|c|}
\hline${ }^{\mathrm{Z}}$ Crosses & $\begin{array}{c}\text { fruit } \\
\text { diameter }\end{array}$ & $\begin{array}{c}\text { Fruit } \\
\text { length }\end{array}$ & $\begin{array}{c}\text { Fruit shape } \\
\text { index }\end{array}$ & TSS & $\begin{array}{c}\text { disease } \\
\text { severity } \\
\text { of roots }\end{array}$ & $\begin{array}{c}\text { disease } \\
\text { severity of } \\
\text { shoots }\end{array}$ \\
\hline $1 \times 2$ & 0.44 & 0.35 & -0.03 & -0.30 & $-3.17^{*}$ & $-2.89^{*}$ \\
\hline $1 \times 3$ & -0.16 & 0.14 & 0.03 & $1.14^{*}$ & $-7.20^{*}$ & $-6.58^{*}$ \\
\hline $1 \times 4$ & -0.30 & 0.12 & 0.01 & 0.08 & 1.38 & 1.42 \\
\hline $2 \times 3$ & 0.42 & 0.40 & -0.02 & -0.68 & $11.03^{*}$ & $9.42^{*}$ \\
\hline $2 \times 4$ & 0.10 & $0.85^{*}$ & -0.01 & 0.58 & $-12.18^{*}$ & $-11.51^{*}$ \\
\hline $3 \times 4$ & $0.59^{*}$ & $0.47^{*}$ & -0.05 & 0.03 & $-12.30^{*}$ & $-10.54^{*}$ \\
\hline S.E. $\left(\mathrm{s}_{\mathrm{ij}}\right)$ & 0.23 & 0.22 & 0.06 & 0.44 & 1.46 & 1.11 \\
S.E. $\left(\mathrm{s}_{\mathrm{ii}} \mathrm{S}_{\mathrm{jij}}\right)$ & 0.31 & 0.27 & 0.05 & 0.42 & 1.40 & 1.06 \\
\hline
\end{tabular}

${ }^{\mathrm{Z}} \mathrm{P} 123235, \mathrm{P} 217171, \mathrm{P} 323096$ and P4 17150.

*Significant at 0.05 level of probability according to the $(\mathrm{T})$ test. 


\section{D-Average degree of heterosis and potence ratio 1- Total yield as weight}

Average degree of heterosis based on mid parent (MP), better parent (BP) and potance ratio (PR) of total yield as weight for six crosses are presented in Table 10. Regarding this trait, all crosses gave significant positive heterosis values from the MP indicating dominance towards the highly total fruit yield. Five crosses gave significant positive heterosis values from the BP indicating hybrid vigour for the trait. One cross viz. $1 \times 3$ reflected over dominance for the high yielding parent.

Four crosses viz. $2 \times 4,3 \times 4,1 \times 2$ and $1 \times 4$ indicated over dominance for the low yielding parents. Only one cross exhibited dominance for high yielding parent viz. $2 \times$ 3 . The similar results were obtained by Khalil and Hatem (2014) who reported that hybrid vigour was also noticed in six crosses for total fruits weight since they showed highly significant positive heterosis values over BP with high potence values.

\section{2- Total yield as number}

Average degree of heterosis based on mid parent (MP), better parent (BP) and potance ratio (PR) of total yield as number for six crosses are presented in Table 10. Regarding the estimates of heterosis based on MP, revealing that positive hybrid vigour for total yield as number was observed in two crosses viz. $2 \times 4$ and $3 \times 4$. While, the estimates of heterosis based on BP it revealed that positive hybrid vigour for total yield as number was observed in one crosses viz. $2 \times 4$. Only one cross viz. $2 \times 4$ reflected over dominance for the highly number of fruit parent. Three crosses viz. 1 $\times 4,1 \times 2$ and $3 \times 4$ indicated over dominance for the low yielding parents. Two crosses viz. $2 \times 3$ and $1 \times 3$ reflected partial dominance for the lowest number of fruit parent.

\section{3- Number of days to $\mathbf{5 0 \%}$ flower anthesis}

Average degree of heterosis based on mid parent (MP), better parent (BP) and potance ratio (PR) for number of days to $50 \%$ flower anthesis for six crosses are presented in Table 10. Regarding the estimates of heterosis based on MP it showed negative hybrid vigour for number of days to $50 \%$ flower anthesis was observed in all crosses. Regarding the estimates of heterosis based on BP it revealed that significant negative hybrid vigour for number of days to $50 \%$ flower anthesis was observed in three crosses viz. $2 \times 3,1 \times 4$ and $1 \times 2$. Only one cross viz. $2 \times 4$ reflected dominance for the highly number day's parent. Two crosses viz. $1 \times 2$ and $1 \times 3$ indicated over dominance for the earlier parent. Two crosses viz. $1 \times 4$ and $2 \times 3$ reflected over dominance for the highly number of days. Only one cross reflected partial dominance for the highly number of days.

These findings were similar to those obtained by Hatem and Salem (2009) and Sood and Kumar (2010) mentioned that the dominance for earlier parent was observed in some crosses in pepper.

\section{4- Average fruit weight}

Average degree of heterosis based on mid parent (MP), better parent (BP) and potance ratio $(\mathrm{PR})$ for average fruit weight for six crosses are presented in Table 10. Regarding the estimates of heterosis based on MP it revealed that positive hybrid vigour for average fruit weight was observed in five crosses. Regarding the estimates of heterosis based on BP, it revealed that significant positive hybrid vigour for average fruit weight was observed in three crosses viz. $3 \times 4,1 \times 4$ and $2 \times 4$. Only one cross viz. $2 \times 3$ reflected over dominance for the heavy weight parent. Two crosses viz. $1 \times 4$ and $2 \times 4$ indicated over dominance for the slight parent. Three crosses viz. $2 \times 3,1 \times 3$ and $1 \times 2$ reflected partial dominance for the slight parent. 


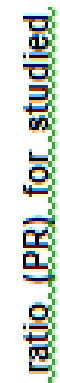

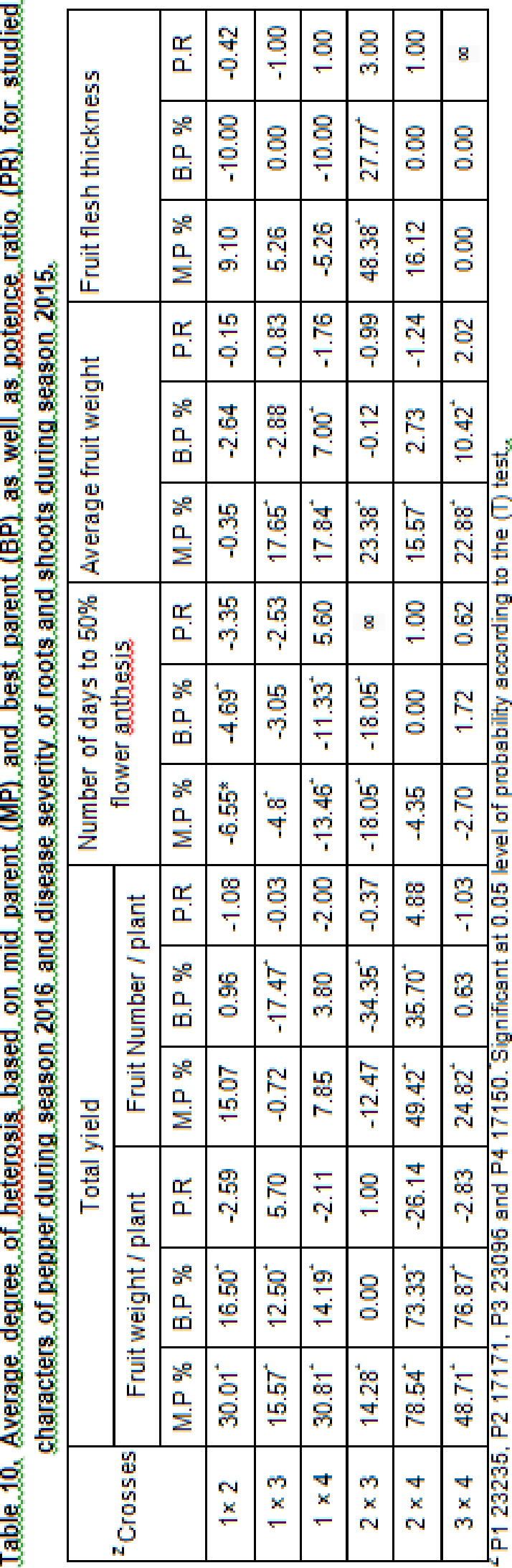

\begin{tabular}{|c|c|c|c|c|c|c|c|}
\hline \multirow{3}{*}{ 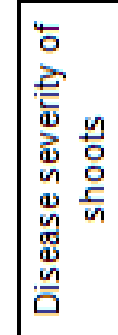 } & $\frac{\alpha}{\alpha}$ & $\frac{\nabla}{\stackrel{\sim}{r}}$ & ণ্ণ & $\stackrel{\infty}{\frac{\infty}{\tau}}$ & 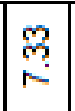 & $\begin{array}{l}0 \\
\text { o } \\
\infty \\
\infty\end{array}$ & $\frac{1}{2}$ \\
\hline & 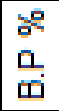 & 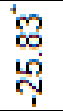 & 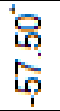 & 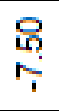 & $\mid \begin{array}{l}\text { 음 } \\
\dot{g}\end{array}$ & $\begin{array}{l}0 \\
0 \\
\infty \\
\infty \\
1\end{array}$ & 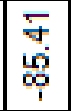 \\
\hline & 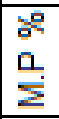 & 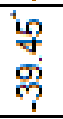 & po & 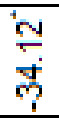 & $\begin{array}{l}g \\
0 \\
0 \\
\end{array}$ & 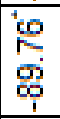 & 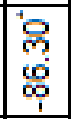 \\
\hline \multirow{3}{*}{ 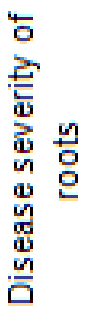 } & $\frac{\alpha}{\alpha}$ & ?ु. & $\begin{array}{l}\text { 号 } \\
\dot{y}+\end{array}$ & 운 & $\mid$\begin{tabular}{l}
$\infty$ \\
\hdashline \\
\hdashline \\
-
\end{tabular} & \begin{tabular}{|l}
0 \\
0 \\
0 \\
1
\end{tabular} & $\begin{array}{l}\text { ஸ్ } \\
\text { के }\end{array}$ \\
\hline & 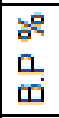 & 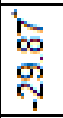 & $\begin{array}{l}9 \\
9 \\
0 \\
0 \\
1\end{array}$ & $\frac{\text { mु }}{\stackrel{m}{1}}$ & 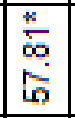 & $\begin{array}{l}\hat{m} \\
\text { m. } \\
\end{array}$ & $\begin{array}{l}k \\
E \\
6 \\
T\end{array}$ \\
\hline & $\begin{array}{l}20 \\
\text { a } \\
\dot{\Sigma}\end{array}$ & 产 & 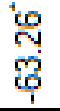 & '8 & 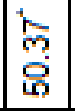 & 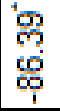 & $\begin{array}{l}18 \\
80 \\
0 \\
10 \\
1\end{array}$ \\
\hline \multirow{3}{*}{ 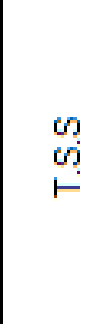 } & $\frac{\alpha}{\alpha}$ & $\frac{8}{\div}$ & 品 & $\stackrel{8}{-}$ & 8 & ল্লে & $\stackrel{8}{-}$ \\
\hline & 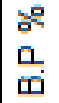 & $\begin{array}{l}\stackrel{\leftrightarrow}{\sim} \\
\dot{y}\end{array}$ & $\begin{array}{l}\stackrel{1}{n} \\
\text { ษ๋ }\end{array}$ & ঙ্? & 8 & $\begin{array}{l}\mathscr{8} \\
\stackrel{8}{\circ}\end{array}$ & 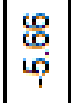 \\
\hline & $\begin{array}{l}2 \\
0 \\
\Sigma \\
\Sigma\end{array}$ & $\begin{array}{l}\text { 寸 } \\
\text { पे }\end{array}$ & $\begin{array}{l}m \\
m \\
m\end{array}$ & 둥 & $\begin{array}{l}8 \\
\\
\end{array}$ & 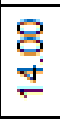 & $\begin{array}{l}8 \\
0 \\
0\end{array}$ \\
\hline \multirow{3}{*}{ 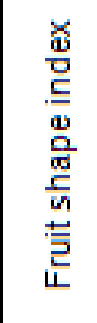 } & $\frac{\alpha}{\alpha}$ & 昌 & $\frac{8}{-}$ & ஸ̃ & $\frac{8}{1}$ & $\frac{0}{\circ}$ & 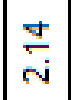 \\
\hline & 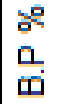 & $\begin{array}{l}\text { \& } \\
\text { 户े }\end{array}$ & $\stackrel{*}{\stackrel{*}{*}}$ & 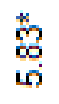 & 8 & $\begin{array}{l}m \\
0 \\
0 \\
0 \\
\end{array}$ & "ִ \\
\hline & $\begin{array}{l}\text { 웅 } \\
0 \\
\Sigma \\
\Sigma\end{array}$ & \begin{tabular}{|l}
1 \\
$\infty$ \\
\cline { 1 - 1 } \\
\cline { 1 - 1 }
\end{tabular} & $\stackrel{\leftrightarrow}{\stackrel{0}{6}}$ & $\stackrel{\text { I }}{\leftarrow}$ & 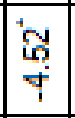 & กั & \begin{tabular}{|l}
0 \\
0 \\
0 \\
1
\end{tabular} \\
\hline \multirow{3}{*}{ 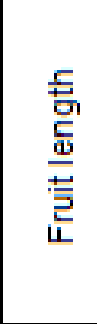 } & $\frac{\alpha}{\alpha}$ & $\underset{ஸ}{\oplus}$ & 产 & 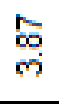 & 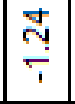 & 8 & $\stackrel{\infty}{\stackrel{一}{\longrightarrow}}$ \\
\hline & $\begin{array}{l}\text { 。̊ } \\
\text { a } \\
\text { ஸ் }\end{array}$ & 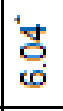 & 을 & ले & $\underset{\check{C}}{E}$ & 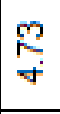 & i̊ \\
\hline & 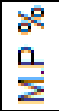 & 占 & $\begin{array}{l}\stackrel{\circ}{R} \\
\text { क }\end{array}$ & ஜु & $\mid$\begin{tabular}{c}
\multirow{y}{*}{} \\
ஸे
\end{tabular} & $\begin{array}{l}m \\
p \\
\dot{p}\end{array}$ & $\mid \begin{array}{l}10 \\
\frac{1}{2} \\
\text { on }\end{array}$ \\
\hline \multirow{3}{*}{ 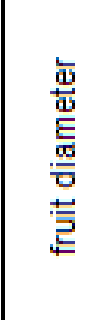 } & $\frac{\alpha}{\alpha}$ & $\frac{1}{\circ}$ & $\begin{array}{l}\text { ¿o } \\
\text { ọ }\end{array}$ & 号 & $\frac{1}{0}$ & $\frac{\widetilde{\sigma}}{-}$ & $\stackrel{m}{\circ}$ \\
\hline & 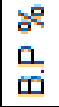 & $\stackrel{\text { ָ̃ }}{\text { ช }}$ & $\stackrel{Ð}{\succcurlyeq}$ & $\frac{\mathscr{\ell}}{T}$ & 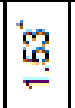 & 守 & 을 \\
\hline & 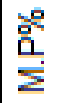 & 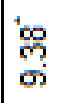 & $\frac{\sigma}{i}$ & i. & 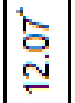 & 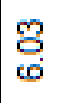 & 올 \\
\hline $\begin{array}{l}d \\
w \\
d\end{array}$ & & $\stackrel{N}{x}$ & $\begin{array}{l}m \\
\times \\
-\end{array}$ & $\begin{array}{l}\dot{x} \\
\stackrel{-}{-}\end{array}$ & $\begin{array}{c}m \\
\stackrel{x}{*} \\
\sim\end{array}$ & $\begin{array}{l}\dot{v} \\
\stackrel{\times}{v}\end{array}$ & $\begin{array}{l}+ \\
\times \\
m\end{array}$ \\
\hline
\end{tabular}


These findings were similar to Khalil and Hatem (2014) who mentioned that most crosses exhibited no dominance for average fruit weight.

\section{5- Fruit flesh thickness}

Average degree of heterosis based on mid parent (MP), better parent (BP) and potance ratio (PR) for fruit flesh thickness for six crosses are presented in Table 10. Regarding the estimates of heterosis based on MP it revealed that positive hybrid vigour for fruit flesh thickness was observed in four crosses viz. $1 \times 2,1 \times 3,2 \times 3$ and $2 \times 4$. Significant positive heterosis was observed on one crosse viz. $2 \times 3$. Regarding the estimates of heterosis based on BP it revealed that significant positive hybrid vigour for fruit flesh thickness was observed in one cross viz. $2 \times 3$. Only two crosses viz. $2 \times 3$ and $3 \times 4$ reflected over dominance for the thick fruit flesh thickness parent. Two crosses viz. $1 \times 4$ and $2 \times 4$ indicated dominance for thick fruit flesh thickness parent. One the other hand, only one cross viz. $1 \times 3$ reflected over dominance for the thin fruit flesh thickness parent and one cross $1 \times 2$ reflected partial dominance for the thin fruit flesh thickness parent.

These findings were disagreed with Khalil and Hatem (2014) mentioned that all the studied $F_{1}$ crosses did not reflect heterotic effects. Meanwhile, incomplete dominance was observed in six crosses.

\section{6- Fruit diameter}

Average degreed of heterosis based on mid parent (MP), better parent (BP) and potence ratio $(\mathrm{PR})$ for fruit diameter for six crosses are presented in Table 10. Regarding the estimates of heterosis based on MP it revealed that positive hybrid vigour for fruit diameter was observed in all crosses. Regarding the estimates of heterosis based on BP it revealed that significant positive hybrid vigour for fruit diameter was observed in three crosses viz. $2 \times 3,2 \times 4$ and $3 \times 4$. Only one cross reflected over dominance for the large parent viz. $2 \times 4$. Three crosses viz. $1 \times 2$, $1 \times 4$ and $3 \times 4$ reflected partial dominance for the large parent. On the other hand, two crosses viz. $1 \times 3$ and $2 \times 3$ indicated partial dominance for the widest parent.

These findings were similar to Khalil and Hatem (2014) mentioned that insignificant $A D H$ values based on MP were estimated for six crosses, suggesting incomplete dominance, while over dominance for large fruit was observed in one cross.

\section{7- Fruit length}

Average degree of heterosis based on mid parent (MP), better parent (BP) and potance ratio (PR) for fruit length for six crosses are presented in Table 10. Estimates of heterosis based on MP, showed that positive hybrid vigour for fruit length in all crosses. While, the estimates of heterosis based on BP revealed positive hybrid vigour for fruit length in all crosses. Four crosses reflected over dominance for the longest parent viz. $2 \times 4,1 \times 2,1 \times 4$ and $3 \times 4$. On the other hand, two crosses reflected over dominance for the short parent viz. $1 \times 3$ and $2 \times 3$.

These findings were agreed to Hatem and Salem (2009) and Sood and Kumar (2010) that mentioned dominance for fruit length. On the other hand, findings of Khalil and Hatem (2014) disagreed the currant study results, where they mentioned that insignificant ADH values based on MP were estimated for six crosses, suggesting incomplete dominance, while over dominance for large fruit was observed in one crosse.

\section{8- Fruit shape index}

Average degree of heterosis based on mid parent (MP), better parent (BP) and potance ratio $(\mathrm{PR})$ for fruit shape index for six crosses are presented in Table 10. Regarding the estimates of heterosis based on MP, the data revealed that positive hybrid vigour for fruit shape index was observed in three crosses viz. $1 \times 3,1 \times 4$ and $2 \times 4$ 
Regarding the estimates of heterosis based on $\mathrm{BP}$, it revealed that significant positive hybrid vigour for fruit shape index was observed in two crosses viz. $1 \times 3$ and $1 \times 4$. In addition, only one cross reflected over dominance for the large parent viz. $3 \times 4$. Two crosses viz. $1 \times 3$ and $2 \times 3$ reflected dominance for the widest parent. On the other hand, one cross viz. $2 \times 4$ indicated over dominance for the widest parent.

\section{9- Total soluble solids}

Average degree of heterosis based on mid parent (MP), better parent (BP) and potance ratio (PR) for TSS for six crosses are presented in Table 10. Regarding the estimates of heterosis based on MP it revealed that positive hybrid vigour for TSS was observed in four crosses. Regarding the estimates of heterosis based on BP it revealed that negative hybrid vigour for TSS was observed in five crosses. Three crosses reflected over dominance for the highest TSS content parent viz. $2 \times 3,1 \times 3$ and $2 \times$ 4. Two crosses reflected dominance for the highest TSS content parent viz. $1 \times 4$ and 3 $\times 4$. On the other hand, one cross reflected dominance for the lowest TSS content parent viz. $1 \times 2$.

These findings were agreed to Khalil and Hatem (2014) who mentioned that dominance for highest TSS parent was observed in two crosses.

\section{0-Disease severity a- Disease severity of roots}

Average degree of heterosis based on mid parent (MP), better parent (BP) and potance ratio $(\mathrm{PR})$ for disease severity of roots for six crosses are presented in Table 10. Regarding the estimates of heterosis based on MP the results revealed that significant negative hybrid vigour for disease severity of roots was observed in all crosses except $2 \times 3$. Regarding the estimates of heterosis based on BP it revealed that significant negative hybrid vigour for disease severity of roots was observed in all crosses except $2 \times 3$. All crosses reflected over dominance for the low parent disease severity except cross $2 \times 3$.This mean that the $F_{1}$ hybrids in pepper could be used as resistant hybrids for this disease.

\section{b- Disease severity of shoots}

Average degree of heterosis based on mid parent (MP), better parent (BP) and potance ratio (PR) for disease severity of shoots for six crosses are presented in Table 10. The estimates of heterosis based on MP revealed that significant negative hybrid vigour for disease severity of shoots was observed in five crosses viz. $1 \times 2,1 \times$ $3,1 \times 4,2 \times 4$, and $3 \times 4$. While, estimates of heterosis based on BP it revealed that negative hybrid vigour for disease severity of shoots was observed in five crosses viz. $1 \times$ $2,1 \times 3,1 \times 4,2 \times 4$, and $3 \times 4$. The same crosses reflected over dominance for the low parent disease severity.

\section{CONCLUSION}

Significant differences were observed among all studied characters. The obtained results reflected generally that the mean squares for general (GCA) and specific (SCA) combining abilities were significant for all the studied traits expect SCA in fruit shape index and fruit flesh thickness, suggesting the presence of both additive and non-additive gene effects in the inheritance of the studied characters. The estimated GCA/SCA mean squares ratio indicated that the additive genetic variance played the main role in the inheritance of total fruit weight as number, average fruit weight, fruit flesh thickness, fruit diameter, fruit length, fruit shape index.

Estimates of GCA effects showed that the best combiner parents were found to be those of P3 for total yield as fruits number and weight, P4 for number of days to $50 \%$ flowering anthesis and TSS content, P1 for average fruit weight, fruit flesh thickness, fruit shape index and low disease severity of roots and shoots, P2 for average fruit weight and fruit length. Estimates of SCA effects 
showed that $F_{1}$ crosses $2 \times 4$ and $2 \times 3$ reflected the highest values in most studied traits i.e. total yield as weight and number, fruit length. All studied crosses were good combinations in low disease severity of roots and shoots except crosses $1 \times 4$ and $2 \times 3$. Finally, the cross $2 \times 4$ was the best cross in this study and good combination for most fruit characters and fusarium resistance with highly degree of heterosis in most fruit characters as well as yield and disease severity of roots and shoots.

\section{REFERENCES}

Abada, K.A. (1994). Fungi associated with root rot of pepper and some factors affecting disease incidence. Proc. 7 th Cong. of Phytopathol. Giza, pp. 219- 226.

Agrios, G.N. (1988). Plant Pathology, $3^{\text {rd }}$ ed. Academic Press, Inc., New York. 803pp.

Agrios, G. N. (1997). Vascular wilts caused by Ascomycetes and imperfect fungi

Arden F. Sherf, Alan A. MacNab (1986). Vegetable Diseases and Their Control, 2nd Edition. 736 pp.

Attia, M.F. and K. A. Abada (1994). Control of Wilt and root rot diseases of pepper Proc. $7^{\text {th }}$ Cong. of Phytopathol, Giza, 397-409 pp.

Attia, M. F., A. M. Arafa, M. A. Mostafa and Mona A. Mohamed (2003). pepper grafting, a method of controlling soil borne diseases and enhancement of fruit yield : 1. Improvement of pepper resistance to fusarium wilt . Egypt. J. Phytopathol.,31:151-165pp.

Black, L. L., S. K.Green, G. L. Hartman and J. M. Poulos (1991). Pepper Diseases: A Field Guide. Asian Vegetable Research and Development Center, AVRDC Publication No. 91-347, 98 pp.

Booth, C. and J. M. Waterston, (1964). Descriptions of pathogenic fungi and bacteria. Commonwcalth Mycological Institute, Ferryland, Kew, Surrey, England .

Bosland, P.W. and E.J. Votava (2012). Pepper: Vegetable and spice Capsicum $2^{\text {nd }}$ end, Center for Agriculture and Biosciences International, Oxford shire, UK, 248 PP.

Domsch, k. H., W. Gams and T. H. Anderson (1980). Compendium of soil fungi. Academic press, London, 859pp

El-Sayed, A. A. (2008). Production of improved chilli pepper hybrids with rootknot nematode resistance. Ph. D. Thesis, Faculty of Agriculture. Cairo University. Egypt, 155pp.

Fekadu, M., L. Dessalegne, C. Fininsa and R. Sigvald (2009). Heterosis and heritability in crosses among Asian and Ethiopian parents of hot pepp genotypes. Euphytica. 168:235-247.

Ferniah, R. S., B. S. Daryono, R. S. Kasiamdari and A. Priyatmojo (2014). Characterization and pathogenicity of Fusarium wilt as the causal agent in Chili (Capsicum annuum L.). Microbiology, 8 (3): 121-126.

Griffing, B. (1956). Concept of general and specific combining ability in relation to diallel cropping systems. Austr. J. Biol. Sci. 9. 463- 495.

Hatem, M.K. and Afaf A. Salem (2009). Genetic studies of some characters in sweet pepper (Capsicum annum, L.). Minufiya J. Agric. Res,.34 (1):163-176.

Horsfall, J. G. and R. W. Barratt (1945). An improved grading system for measuring plant diseases. Phytopathology 35: 655.

Huang, Z., P. Laosuwan, T. Machikowa and Z. Chen (2009). Combining ability for seed yield and other characters in rapeseed. Suranaree J. Sci. \&Techn., 17(1): 39-47.

Jagdeesha, R.C. and M.C. Wali (2005). Genetic analysis of dry fruit yield and its component in chilli (Capsicum annuum L.). Vegetable Science 32(1): 37-40.

Jones, M. M. (1992). Fusarium wilt of pepper: Response of Capsicum spp. accessions to Fusarium oxysporum f.sp. capsici and analysis of vegetative 
combatibility. M.S. thesis, Louisiana State University, Baton Rouge. 69 pp.

Joshi, M., R. Srivastava, A. K. Sharma and A. Prakash (2015). Screening of resistant varieties and antagonistic Fusarium oxysporum for biocontrol of Fusarium wilt of Chilli. J Plant Pathol Microb, 3:134.

Kamble, C., R. Mulge and M. B. Madalageri (2009). Combining ability for earliness and productivity in sweet pepper (Capsicum annum, L.). Karnataka J. Agric. Sci. 22(1): 151-154.

Kansouh, A. M. A. (1989). Studies on heterosis and nature of gene action in pepper. M.Sc. Thesis. Fac. Agric., Minufiya univ., Egypt. 176 p.

Khalil, M. R. and M. K. Hatem (2014). Study on combining ability and heterosis of yield and its components in (Capsicum annum, L.). Alex. J. Agric. Res. 59 (1): 61- 71.

Koch, Gary, G. and P. K. Sen (1968). Some aspects of the statistical analysis of the mixed mode.1. Biometrics 24: 27-48.

Lomas-Cano, T., A. Boix-Ruiz, de CaraGarcía, M. Marín-Guirao, J.I. PalmeroLlamas, D. Camacho- Ferre, F. and J. C. Tello-Marqui (2016). Etiological and epidemiological concerns about Pepper root and lower stem rot caused by Fusarium oxysporum f. sp. radicis-capsici f. sp. nova, pp 283-293

Mushtaq, M. and M.H. Hashmi (1997). Fungi associated with wilt disease of Capsicum in Sindh, Pakistan. Pak. J. Bot., 29(2): 217-222.

Nelson, P. E., T. A. Toussoun and W.F.O. Marasas (1983). Fusarium species: An Illustrated Manual of Idenntification. Pennslvania Univ. Press, Univ. Park ,193 pp.

Pandey, V., A. Chura, H.K. Pandey, H.S. Meena, M.C. Arya and Z. Ahmed (2012). Diallel analysis for yield and yield attributing traits in Capsicum (Capsicum annuum L. var grossum Sendt). J. Agric. Sci 33: 178-179.
Rather, T. R., V. K. Razdan, A. K. Tewari, Z. A. Efath Shanaz, M. G. Bhat, Hassan and T. A. Wani (2012). Integrated Management of Wilt Complex Disease in Bell Pepper (Capsicum annuum L.). Journal of Agricultural Science; 4(7):141147.

Rêgo, E. R., M. M. Rêgo, C.D. Cruz and F.L. Finger (2010). Phenotypic diversity, correlation and importance of variables for fruit quality and yield traits in Brazilian peppers (Capsicum baccatum). Genetic Resources and Crop vol. 58 (6): 909-918.

Rivelli, V. (1989). A wilt of pepper incited by Fusarium oxysporum f.sp. capsici forma specialis nova. M.S. thesis, Louisiana State University, Baton Rouge. 72 pp.

Roberts, P. D., S. Adkins, K. Pernezny and J. B. Jones (2004). Diseases of Pepper and their Management. In: Naqvi S.A.M.H. (eds) Diseases of Fruits and Vegetables: Volume II. Springer, Dordrecht

Sarhan, A. R. T. and F. M. Sharif (1986). Integrated control of fusarium Wilt of pepper.Act .Phytopathol.Entomologica Hungarica, 21:123-126.

Sarujpisit, P., D. Boonyakiat and M. Nikornpun (2012). Evaluation of heterosis and combining ability of yield components in Chillies. J. Agric. Sci. 4 (11): $154-161$.

Sherf, A. F. and A. A. McNab (1986). Vegetable diseases and their control. 2nd Edit. John Wiley \& Sons. 728 pp.

Singh, R.S. (1989). Plant Diseases (6 $6^{\text {th }} E d$.) IBH \& Oxford Publ. Co. New. Delhi. 422424.

Sinha, S.K. and R. Khanna (1975). Physiological, biochemical and genetic basis of heterosis. Advan.Agron. 27: 123174.

Smith, H. H. (1952). Fixing transgressive vigour in Nicotiana rustica. In heterosis, lowa State College, Press. Ames, lowa ,U.S.A. 
Snedecor, G. W. and W.C. Cochran (1990). Statistical Method. 7th ed. The lowa State Univ. Ames. USA. 593 p.

Sood, S. and S. Kaul (2006). Heterosis in intraspecific hybrids for quantitative traits of bell pepper. Vegetable Science 39 (2): 136-139.

Sood, S. and N. Kumar (2010). Heterotic expression for fruit yield and yield components in intervarietal hybrids of sweet pepper (Capsicum annum, L. var. grossum Sendt). Sabrao J. Breed. \& Genet. 42(2):105-115.
Stover, R.H. (1962). Fusarium Wilt (Panama Disease) of Bananas and other Musa species. Phytopathological Paper No. 4. Wallingford, UK: CAB International. Survey on major diseases of vegetable and fruit crops in Chittagong region.

Walker, J.C. (1952). Disease of Vegetable Crops. McGraw Hill Book Co., London. 529pp.

Wollenweber, H.W. (1913). Studies on the Fusarium problem. Phytopathology, 3:2449. 


\section{تقدير قوه الهجين و الفعل الجيني و طبيعه المقاومه لمرض ذبول الفيوزاريوم فى هجن القلقل الحلو}

عبير عبد القادر سليمان (1) ، إيمان يحيى خفاجى(2)

(1) قسم بحوث تربيه الخضر - معهز بحوث البساتين-مركز البحوث الزراعية -الجيزه

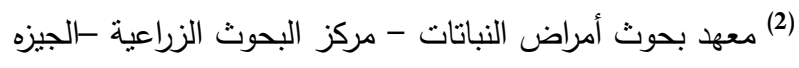

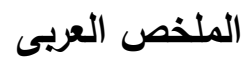

استخدمت فى هذه الدراسة أربع أباء مستوردة من مركز الاصول الوراثية بهولندا وهما الاب الاول 23235 و الاب الثانى

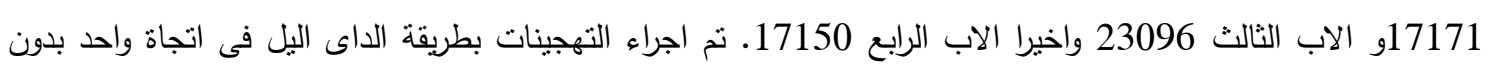

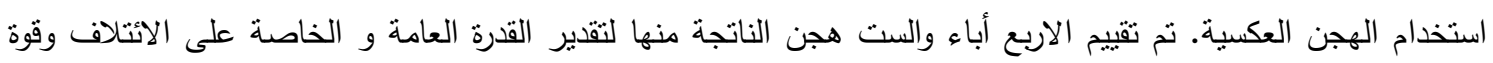

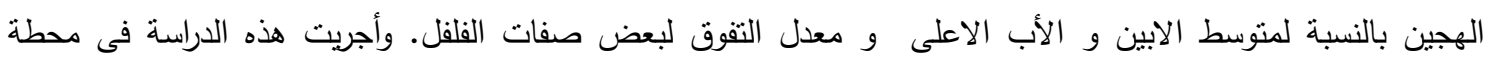
التجارب الزراعية بقها بمحافظة القليوبية فى خلال الموسمين 2015و 2016 فى صوبه لالابل بلاستيكيه غير مدفأه.

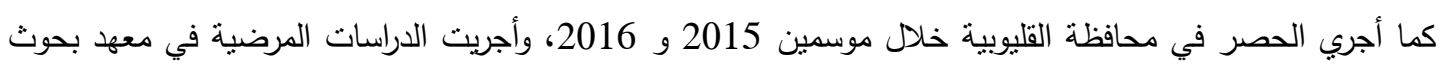

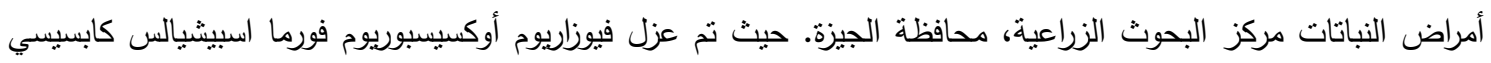

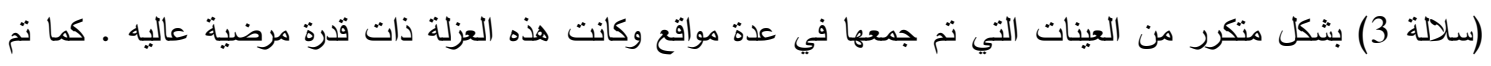

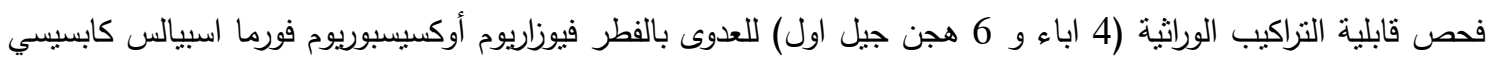

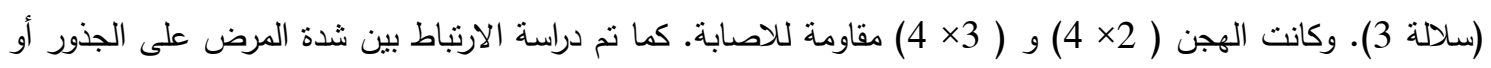

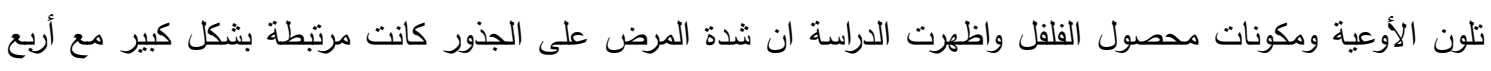

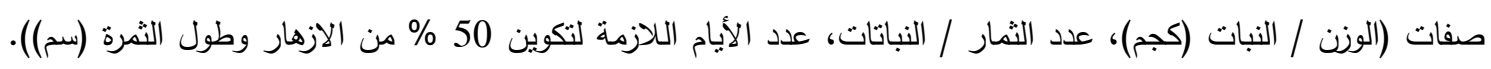

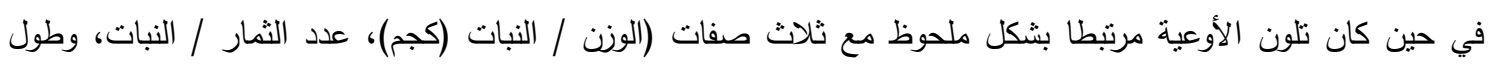
الثمار (سم) ) كما نم تقييم الأباء و الهجن الناتجة منها من حيث المحصول و مكوناتة والمقاومة للذبول الفيوزارمى وتقدير القدرة العامة والخاصة للتألف وتأثثير قوة الهجين. وقد اوضحت النتائج معنوية تباين كل من القدرة العامة و الخاصة على الائتلاف فى كل الصفات المدروسة فيما عدا

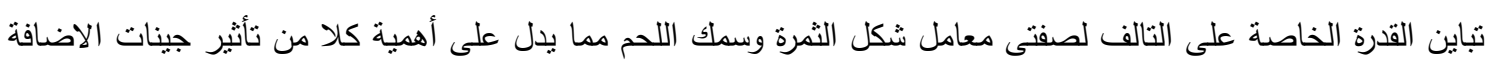

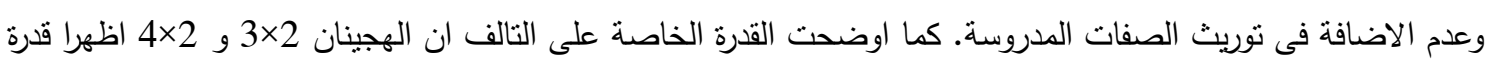
خاصة عالية في كل الصفات المدروسة مثل المحصول الكلى من حيث وزن وعدد الثمار وطول الثمرة و انخفاض شدة الثدات الاصابة في الجذور والسيقان.

كما اوضحت الدراسة ان كل الهجن المدروسة كانت هجن جيدة من حيث انخفاض معدل الاصابة وشدتها في الجذور و

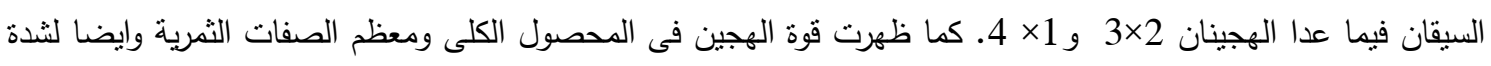
الاصابة ـ أظهرت بعض الهجن قوة هجين و معدل التفوق لتعزيز السيادة. 